\title{
EFEKAT DEJSTVA ELEKTROMAGNETNOG ZRAČENJA BEŽIČNIH MREŽA I MOBILNIH TELEFONA NA ZDRAVLJE LJUDI
}

\author{
Emilija Spasić ${ }^{1}$ \\ Slađana Spasić2, 3,*, \\ Violeta Tomašević ${ }^{3}$
}

${ }^{1}$ Fakultet organizacionih nauka, Univerzitet u Beogradu,

Beograd, Srbija

${ }^{2}$ Institut za multidisciplinarne studije, Univerzitet u Beogradu,

Beograd, Srbija

${ }^{3}$ Univerzitet Singidunum,

Beograd, Srbija

Odgovorno lice:

Slađana Spasić

e-pošta:

sladjana.spasic@singidunum.ac.rs
Rezime:

U radu su predstavljena najnovija istraživanja uticaja elektromagnetnih zračenja, prouzrokovanih masovnom primenom bežičnih digitalnih elektronskih uređaja, na zdravlje ljudi i životnu sredinu. Ukazano je na potencijalan uticaj $5 \mathrm{G}$ mreža, mobilnih telefona, baznih stanica i poboljšanih bežičnih telefona na učestalost pojave malignih i nemalignih tumora na mozgu, kognitivnih i drugih poremećaja kod ljudi. Ukazano je i na aktivnosti raznih međunarodnih tela koja pokušavaju da uspostave zakonsku regulativu u ovoj oblasti. S obzirom da se na osnovu do sada dobijenih rezultata ne može sa pouzdanošću dokazati da li nove tehnologije donose više koristi ili štete ljudima i životnoj sredini, došlo je do polarizacije stručne javnosti u svetu po ovim pitanjima. Danas su sa jedne strane industrijski konzorcijumi koji ulažu velika sredstva u razvoj novih tehnologija, a sa druge strane oni koji osporavaju opravdanost ulaganja koja potencijalno ugrožavaju zdravlje ljudi.

Ključne reči:

radio talasi, elektromegnetno zračenje, mobi-lni uređaji, 5G mreža, zdravlje ljudi.

\section{UVOD}

Biološki sistemi su permanentno izloženi elektromagnetnim poljima (EMF - Electromagnetic Field) u obliku prirodnih geomagnetskih polja i elektromagnetnih polja emitovanih od strane tehničkih uređaja. Mnoge nove tehnologije, kao što su bežični prenos snage ili indukcioni kućni štednjaci, proizvode električna polja (EF - Electric Field), magnetna polja (MF - Magnetic Field) ili elektromagnetna polja u opsegu srednjih frekvencija (300 do $3000 \mathrm{kHz}$ ). Međutim, efekti takvih polja na biološke sisteme su, uprkos pojačanom interesovanju naučne zajednice, još uvek nedovoljno istraženi i kontroverzni [1]. Široko su rasprostranjeni zabrinutost i spekulacije u pogledu emisije radio frekvencija i elektromagnetnih polja (RF-EMF - Radiofrequency Electromagnetic Field) od strane telekomunikacionih baznih stanica i struktura, jer se neke od njih smatraju nesigurnim i opasnim za javno zdravlje. Naučnici, medicinski stručnjaci, političari, novinari i stručnjaci u kompanijama koje se bave mobilnim telekomunikacijama uključeni su u aktivnu debatu o tome da li su ljudi, ostali živi svet i okolina imuni na radio frekvencije ili se ponašamo neodgovorno prema sopstvenoj budućnosti [2]. 


\section{UTICAJ 5G MREŽE NAZDRAVLJE LJUDI}

Naučna istraživanja pokazuju da postojeće bežične tehnologije 2G, 3G i 4G, koje se koriste u mobilnoj telefoniji, računarima i mobilnoj tehnologiji uopšte, predstavljaju ozbiljan zdravstveni rizik po ljude, životinje, biljke i životnu sredinu zbog izloženosti talasima iz područja radio spektra [3].

Za opisivanje nove generacije mobilnih mreža razvijenih posle 4G LTE mobilnih mreža koje su danas u upotrebi, uveden je termin 5G. Peta generacija mobilnih tehnologija ili 5G mreža omogućava prenos velikih količina podataka velikom brzinom. Ona treba da bude podrška novoj tehnologiji koja omogućava postojanje „internet stvari“" (Internet of Things), kao i povezivenje u sistem svih uređaja koji imaju Internet vezu. Međutim, 5G mreža može znatno da ugrozi naše zdravlje. $U$ dokumentima kompanija koje se bave bežičnim tehnologijama jasno se navodi da će se sa uvođenjem $5 \mathrm{G}$ mreže povećati nivo radiofrekventnog zračenja u blizini mrežnih antena. Naučnici upozoravaju da, pre nego što počne sa radom $5 \mathrm{G}$ mreža, treba neizostavno sprovesti istraživanja o uticajima ove mreže na ljudsko zdravlje kako bi se osiguralo da javnost i životna sredina budu zaštićeni. Mnoge zemlje poput Kine, Indije, Poljske, Rusije, Italije i Švajcarske imaju vrlo stroge, zaštitne zakonske propise u vezi praga zračenja, tako da neće dozvoliti rasprostiranje $5 \mathrm{G}$ mreže preko svojih teritorija, jer bi povećano zračenje $5 \mathrm{G}$ mreže premašilo dozvoljene granice zračenja u ovim zemljama. Sa jedne strane, navedene zemlje postavljaju prepreke za uvođenje 5G tehnologije, a sa druge strane industrija ulaže velike napore kako bi se oslobodila tih ograničenja [4].

I pred toga što uvođenje $5 \mathrm{G}$ mreže u Evropi zahteva ogromnu investiciju od čak 500 milijardi dolara, za koju se ne može tvrditi da je u potpunosti isplativa, kao ključno, postavlja se pitanje da li je dopustivo ugroziti zdravlje ljudi radi bržeg prenošenja podataka.

Sve veći broj naučnih studija ukazuje na to da visokofrekventno elektromagnetno zračenje koje koriste mobilne tehnologije može naneti štetu ljudskom zdravlju izazivajući rak ili oštećenje muških polnih ćelija. Svetska zdravstvena organizacija, kao i druge kompetentne institucije, prepuštaju odgovornost malim grupama ljudi koje postavljaju granice za zaštitu populacije. Pri tome, veliki broj značajnih informacija koje se tiču zaštite ostaju sakrivene. Više od 400 fizičara i naučnika u internacionalnoj žalbi (peticiji) iz 2019. godine, u kojoj se zalažu za prestanak širenja $5 \mathrm{G}$ tehnologije, upozorava da implementacija 5G mreže preti da ostavi ozbiljne i nepovratne posledice na ljudsko zdravlje.
Biolozi, lekari i inženjeri već dve decenije istražuju uticaj radiofrekventnog zračenja koje potiče od mobilnih uređaja na zdravlje ljudi. Na najvećoj Internet platformi sa informacijama na ovu temu „EMF-Portal“, realizovanoj na RWTH Univerzitetu u Ahenu, nalazi se više od 2000 naučnih studija. Prema proceni rezultata istraživanja, naučnici imaju duboko podeljena mišljenja u vezi sa ovom temom. Ova podeljenost mišljenja među stručnjacima proizilazi iz činjenice da je zagrevanje tkiva, do koga dolazi kada se tkivo izloži visokim dozama ovog zračenja, za sada jedini dokazan štetan efekat radiofrekventnih elektromagnetnih polja na zdravlje ljudi. Prema ICNIRP-u, postoji rizik da će energija koja se prenosi zračenjem dostići više od $2 \mathrm{~W} / \mathrm{kg}$ telesne težine. Međunarodna komisija za zaštitu od nejonizujućeg zračenja (ICNIRP - International Commission on Non-Ionizing Radiation Protection) je privatno naučno udruženje koje nema zvaničan karakter, ali zakoni koji štite ljude od visokofrekventnog zračenja strogo prate smernice ovog udruženja.

Analiza pozitivnoh efekata koje može da nam donese uspostavljanje $5 \mathrm{G}$ mreže pokazuje da je izgleda njena korisnost ipak marginalna, osnosno nije tolika da bismo zbog nje ugrozili sopstveno zdravlje. Tomas Magedanc (Thomas Magedanz), nemački naučnik i ekspert u oblasti telekomunikacija koji vodi $5 \mathrm{G}$ istraživanje na Fraunhofer institutu za komunikacione sisteme u Berlinu, objašnjava da za korisnike pametnih telefona, uvođenje $5 \mathrm{G}$ mreže pruža veoma malu direktnu korist jer postojeća $4 \mathrm{G}$ tehnologija već omogućava korisnicima mnogo toga. Kako on navodi, mnogo bi veća bila potencijalna indirektna korist od uvođenja 5G mreže koja se, na primer, ogleda u tome da bi u budućnosti ova mreža mogla da bude u funkciji bezbednog umrežavanja uređaja u bolnicama ili da služi kao privremena mreža na različitim događajima.

Trenutno, vlada Evropske unije vrši pritisak na mrežne operatere da što pre kupe licence za frekvencije koje su im potrebne od vlade, iako još nije jasno kako će opravdati takav trošak. U Nemačkoj i još osam drugih zemlja evropske ekonomske zone ova akcija i dalje traje. Selektivni otpori grupe naučnika uvođenju $5 \mathrm{G}$ mreže nisu dovoljni da bismo bili zaštićeni od potencijalne štete koja bi nastala uvođenjem ove mreže. Evropska unija trenutno ulaže 700 miliona evra u projekte razvoja $5 \mathrm{G}$ mreže, međutim nijedan od ovih projekata ne odnosi se na istraživanje rizika. Rizici koje nosi uvođenje 5G mreže su još uvek nepoznati i nedovoljno istraženi, dok je investicija u razvoj ogromna. U cilju zaštite ljudskog zdravlja, ali i smanjenja rizika od neuspeha ogromne investicije, možda je vreme da Evropska unija promeni prioritete u okviru ovog programa. 


\section{UTICAJ ELEKTROMAGNETNOG ZRAČENJA MOBILNIH TELEFONA NA ZDRAVLJE LJUDI}

Mikrotalasi su elektromagnetni talasi sa frekvencijama od 1 do $300 \mathrm{GHz}$ čija je primena široko rasprostranjena u savremenom društvu. Mobilni telefoni rade na frekvencijama UHF (Ultra High Frequency) talasa u opsegu od $300 \mathrm{MHz}$ do $3 \mathrm{GHz}$, u zavisnosti od tipa telefona i dizajna. Uobičajena četiri frekvencijska opsega u kojima rade mobilni telefoni su 850/900/1800/1900 MHz.

Elektromagnetno zračenje uopšte može biti apsorbovano od strane organizma, pri čemu izaziva niz fizioloških i funkcionalnih promena. Poznato je da jaka elektromagnetna polja menjaju brzinu hemijske reakcije i koncentracije slobodnih radikala u organizmu. Mnoge složene električne aktivnosti koje se javljaju u centralnom nervnom sistemu, uključujući učenje i pamćenje, stoga su podložne uticaju elektromagnetnog zračenja. Štaviše, intenzivna upotreba mobilnih telefona učinila je elektromagnetno zračenje glavnim izvorom zračenja mozga. Zbog toga se centralni nervni sistem smatra jednim od najosetljivijih organa koji je meta mikrotalasnog zračenja.

Veliki broj studija je pokazao da mikrotalasno zračenje može izazvati niz neželjenih reakcija u centralnom nervnom sistemu, uključujući poremećaje spavanja, smanjenje sposobnosti učenja i pamćenja, itd. [5]. U [5] Zhi i sar. navode da od brojnih studija koje su sprovedene da bi se istražili efekti mobilnih komunikacionih uređaja na ljude, samo nekoliko je pokazalo da su mobilni telefoni i tumori mozga statistički povezani. Tako, ljudi koji su koristili mobilne telefone više od 10 godina imaju veći rizik od pojave tumora mozga. Takođe, oni koji su navikli da koriste svoj mobilni telefon pretežno sa iste strane imaju dvostruko veću verovatnoću pojave tumora mozga od onih koji to ne čine. Međutim, većina studija nije podržala zaključak da mobilni telefoni izazivaju tumore mozga. Jedna studija koju je objavila istraživačka grupa Interphone [6] pokazala je da ne postoji povećanje rizika od glioma ili meningioma kod korisnika mobilnih telefona. Pored toga, Larjavaara i sar. su u [7] otkrili da se gliomi ne nalaze nužno u oblastima mozga sa najvećom izloženošću zračenju.

Epidemiološke studije o korišćenju mobilnih telefona se trenutno sprovode širom sveta, ali naučni dokazi još uvek nisu dovoljno ubedljivi. Najnovija studija izvedena u Japanu [8] je imala za cilj da simulira učestalost malignih tumora mozga u kohortama koje su počele da koriste mobilne telefone kada su oni postali popularni u Japanu. Kako je prošlo više od 20 godina od početka upotrebe mobilnih telefona u Japanu, podaci o vlasnicima mobilnih telefona prikupljani su putem upitnika koji je sproveden putem Interneta, a ispitanici su rođeni između 1960. i 1989. godine. Udeo vlasništva nad mobilnim telefonom između 1990. i 2012. godine izračunat je po kohorti rođenja: 1960-ih, 1970-ih i 1980-ih. Nakon toga, koristeći udeo vlasništva, izračunata je učestalost malignih tumora mozga simulirajući rizične uslove. Kada je relativni rizik postavljen na 1,4 za 1640 h ili više kumulativne upotrebe mobilnih telefona, i kada je pretpostavljena srednja dnevna dužina poziva od 15 min. incidencija malignih tumora mozga u 2020. godini bila je 5,48 na 100.000 stanovnika za porodicu iz kohorte 1960-ih, 3,16 za kohortu rođenih 1970-ih, i 2,29 za kohortu rođenih 1980-ih godina (sl. 1). Prema modeliranim scenarijima, očekivano povećanje incidencije malignih tumora mozga se pokazalo oko 2020. godine [8]. Ova studija je otkrila da se u modeliranim scenarijima, povećanje incidencije malignih tumora mozga očekuje oko 2020. godine, ali i da treba ispitati da li, i u kojoj od ispitivanih kohorti, postoji povećana incidencija malignih tumora mozga.

\section{Incidencija malignih tumora}

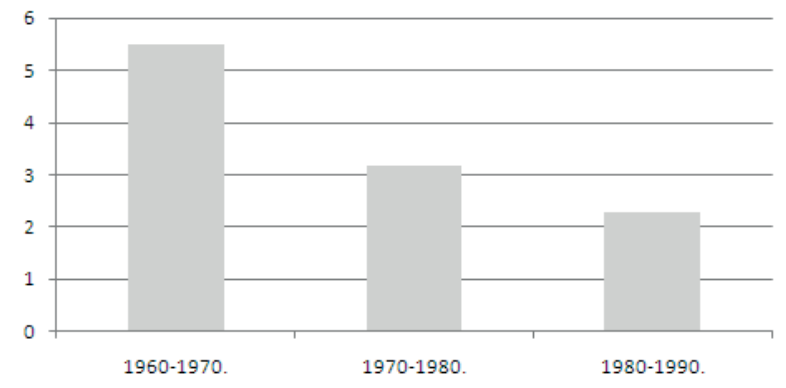

Sl. 1. Učestalost malignih tumora mozga u 2020. godini na 100.000 stanovnika po periodima rođenja

Tehnologije koje se brzo menjaju i intenzivna upotreba radiofrekventnih elektromagnetnih polja predstavljaju izazov za javno zdravlje. Broj korisnika mobilnih telefona, kao i korišćenje i izloženost drugim bežičnim uređajima za prenos podataka (WDT- Wireless Device Transmitter) povećali su se u proteklih nekoliko godina (sl. 1).

CERENAT je francuska nacionalna studija koja analizira upotrebu mobilnih telefona i rizik od nastanka tumora mozga. Nalaz CERENAT-a o povećanom riziku od glioma je u skladu sa rezultatima studijama urađenim u protekloj deceniji ili ranije, koje procenjuju efekte 
primene mobilnih telefona [9]. Ova studija je imala za cilj analizu povezanosti između izloženosti zračenju mobilnog telefona i primarnih tumora centralnog nervnog sistema (glioma i meningioma) kod odraslih. Analizirano je ukupno 253 glioma, 194 meningioma i 892 odgovarajućih kontrola odabranih iz lokalnih biračkih spiskova. Nije primećena povezanost sa tumorom mozga kada se upoređuju redovni korisnici mobilnih telefona sa ne-korisnicima. Međutim, pozitivna asocijacija je bila statistički značajna kod najtežih korisnika kada se razmatra životno kumulativno trajanje razgovora ( $\geq 896 \mathrm{~h}$ za gliome i meningiome) i broj poziva za gliome ( $\geq 18.360$ poziva). Rizici su bili veći kod glioma, temporalnih tumora, profesionalne i urbane populacije koja koristi mobilne telefone. Iako karcinogeni efekat radiofrekventnih elektromagnetnih polja kod ljudi ostaje kontroverzan, podaci studije [9] podržavaju prethodna saznanja o mogućoj povezanosti između veće upotrebe mobilnih telefona i tumora mozga, pa je predloženo da bi se mogli uključiti u etiologiju nekih tipova tumora mozga.

U CERENAT-u, izloženost radiofrekventnim elektromagnetnim poljima iz digitalno poboljšanih bežičnih DECT telefona (DECT - Digital Enhanced Cordless Telecomunications), koje je koristilo više od polovine populacije Francuske tokom perioda ove studije, nije evaluirana. Ako se uzme u obzir izloženost i DECT, kao i mobilnim telefonima, rizici od glioma su verovatno veći od objavljenih u CERENAT-u. Zato autori studije [10] zaključuju da bi radiofrekventna polja trebalo klasifikovati u Grupu 2A kao potencijalno karcinogena po ljude, a prema kriterijima koje koristi Međunarodna agencija za istraživanje raka (Lion, Francuska). Morgan i sar. u [10] takođe smatraju da je potrebno prikupiti dodatne podatke o izloženosti mobilnim i bežičnim telefonima, drugim bežičnim uređajima za prenos podataka, baznim stanicama mobilnih telefona i Wi-Fi ruterima kako bi se procenio i njihov uticaj na javno zdravlje.

Jasno je da je društvo sve više zabrinuto zbog efekata koje elektromagnetno polje radiofrekventnog opsega može da ima na ljudsko zdravlje, paralelno sa povećanjem izloženosti ljudi. Pojava uređaja za merenje ličnog izlaganja izloženosti zračenju otvara široke mogućnosti za istraživanja. Uprkos studijama koje su karakterisale izloženost ličnosti RF-EMF-u, deo populacije je još uvek zabrinut, u tolikoj meri da se pojavljuju čak i psihogeni, tj. "nocebo" efekti. Ideja najnovije studije date u [11] je bila analiza rezultata lične izloženosti RF-EMF-u u Albaceteu (166.000 stanovnika, SE Španija). Cilj je bio da se proceni efekat rezultata studije na percepciju učesnika studije u pogledu rizika, kako bi se bolje razumeo i promovisao značaj javnog zdravlja. Merenja su izvršena ličnim Satimo EME SPY 140 meračem izloženosti, koji je programiran da meri izloženost na svakih 10 sekundi u toku 24 sata. Studija je sprovedena na 75 volontera. Analizirano je njihovo lično izlaganje u 14 mikrookruženja u gradu, na primer, kod kuće, napolju, na poslu, itd. i razmatrane moguće razlike između izloženosti u tim mikrosredinama. Nakon učešća u studiji, 35 učesnika je popunilo upitnik o njihovoj RF-EMF percepciji rizika. Na upitnik je odgovorio i kontrolni uzorak od 36 ispitanika radi poređenja rezultata. Ukupna prosečna izloženost na 14 mesta mikrookruženja bila je $37,7 \mu \mathrm{W} / \mathrm{m}^{2}$, a pojedinačni opsezi su bili između $0,2 \mu \mathrm{W} / \mathrm{m}^{2}$ i maksimalno $264,7 \mu \mathrm{W} / \mathrm{m}^{2}$ u DECT bežičnim uređajima. Takođe je utvrđeno da je za petak zabeležena srednja vrednost od $53,9 \mu \mathrm{W} / \mathrm{m}^{2}$, za razliku od $23,4 \mu \mathrm{W} / \mathrm{m}^{2}$ koja je dobijena za subotu. Zabeležena vrednost za noćnu izloženost iznosila je 27,5 $\mu \mathrm{W} / \mathrm{m}^{2}$ nasuprot $43,8 \mu \mathrm{W} / \mathrm{m}^{2}$ zabeleženih u toku dana. Prosečna vrednost izloženosti je takođe pokazala razlike između radnih dana i vikenda, sa $39,7 \mu \mathrm{W} / \mathrm{m}^{2}$ i $26,9 \mu \mathrm{W} /$ $\mathrm{m}^{2}$, respektivno. Glavni izvori koji su najviše doprineli srednjoj ukupnoj ličnoj izloženosti bili su DECT uređaji sa $50,2 \%$, zatim mobilni telefoni sa $18,4 \%$ i stanice sa $11,0 \%$, dok je Wi-Fi signal imao udeo od 12,5\% (sl. 2).

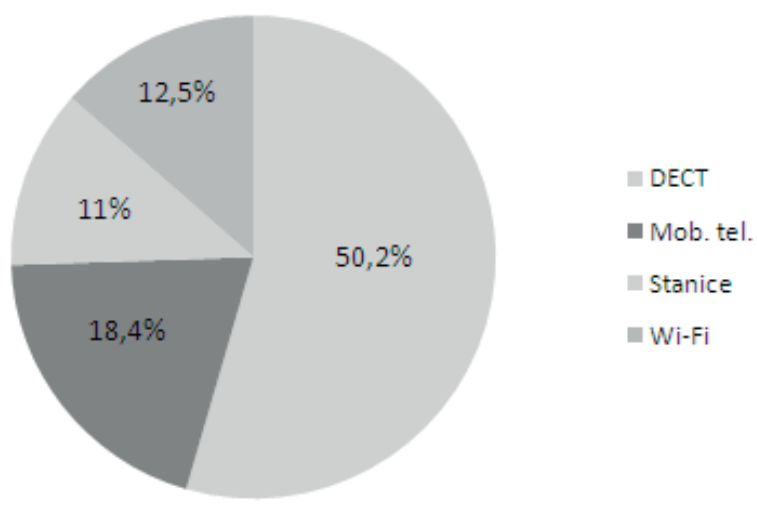

Sl. 2. Udeo izvora zračenja u ličnoj izloženosti

$\mathrm{U}$ analiziranim mikrosredinama srednja izloženost domova i radnih mesta iznosila je $34,3 \mu \mathrm{W} / \mathrm{m}^{2}$, odnosno $55,2 \mu \mathrm{W} / \mathrm{m}^{2}$, respektivno. Na otvorenom, srednja vrednost je bila $34,2 \mu \mathrm{W} / \mathrm{m}^{2}$, a glavni izvori bili su DECT, Wi-Fi i mobilne telefonske stanice, u zavisnosti od mesta. Analiza percepcije rizika pokazala je da $54 \%$ ispitanika smatra da su RF-EMF manje opasna nego što su to mislili pre učešća u istraživanju, dok $43 \%$ nije navelo 
promene u percepciji. Samo 9\% volontera koji su dobili informacije o svojim merenjima nakon studije procenili su mogući rizik RF-EMF-a vrednošću koja je veća ili jednaka 4 (na skali od 1 do 5) naspram 39\% kontrola koje nisu učestvovale. Ramirez-Vazquez i sar. su u [11] zaključili da je izloženost RF-EMF-u opala znatno ispod granica preporučenih od strane ICNIRP-a i da je pokazala široku vremensku i prostornu varijabilnost. Glavni izvori izloženosti bili su bežične telekomunikacione mreže (DECT), zatim mobilni telefoni i Wi-Fi. Saopštavanje rezultata o izloženosti učesnicima studije je smanjilo njihovu percepciju rizika. Studije o kontroli upotrebe bežičnih telefona i riziku od pojave tumora na mozgu obično nisu proučavale stepen izloženosti glave zračenju bežičnih DECT telefona, a upravo ova studija je pokazala da su bežični telefoni doprineli sa $50 \%$ ukupnoj izloženosti radiofrekventnom zračenju, što je znatno u poređenju sa samo $18 \%$ od mobilnih telefona. Sledi da većina studija verovatno potcenjuje efekat upotrebe bežičnog telefona na rizik obolevanja od tumora mozga.

Najnovija studija Meo i sar. opisana u [12] ispitivala je uticaj baznih stanica mobilnih telefona postavljenih u blizini školskih zgrada na kognitivno zdravlje učenika. Dokazano je da je visoka izloženost RF-EMF-u koju proizvode bazne stanice mobilnih telefona bila povezana sa odloženim finim i ostalim motoričkim reakcijama, smanjenjem radne memorije i pažnje kod adolescenata u školi u blizini bazne stanice u odnosu na učenike koji su bili izloženi niskom RF-EMF-u.

Miller i sar. u [13] izveštavaju da epidemiološke studije (kontrola slučaja, kohorte, vremenski trend i studije slučaja) objavljene 2011. i podržane od strane Međunarodne agencije za istraživanje raka (IARC - International Agency for Research on Cancer), koja radi u okviru Svetske zdravstvene organizacije, kategorišu radiofrekventno zračenje sa mobilnih telefona i drugih bežičnih uređaja kao mogući karcinogen za ljude (Grupa 2B). Gliom je važan karcinom koji se javlja kod ljudi za koji se otkrilo da je povezan sa radiofrekventnim zračenjem u 9 studija slučaja-kontrole sprovedenih u Švedskoj i Francuskoj, kao i u nekim drugim zemljama. Povećanje trendova incidencije glioma zabeleženo je u Velikoj Britaniji i drugim zemljama, dok nemaligni ishodi bolesti uključuju akustični neurom i meningiom. Kada se uzmu u obzir nedavni eksperimenti na životinjama, nedavne epidemiološke studije osnažuju i podupiru zaključak da bi radiofrekventna zračenja trebalo kategorizovati kao karcinogene za ljude (IARC Grupa 1).

\section{DISKUSIJA I ZAKLJUČAK}

Zbog velike heterogenosti u dizajnu studija, ishoda i izloženosti sistema, kao i nedoslednih rezultata i metodičkih ograničenja u mnogim studijama, Bodewein i sar. u [1] smatraju da kvalitet dokaza za neželjene efekte ostaje nedovoljan za donošenje konačnog zaključka o istraživanim biološkim efektima EMF polja. Smatraju da u budućim istraživanjima efekti EF, MF i EMF treba da se istraže sistematičnije, tj. da studije treba da uzmu u obzir različite frekvencije (da bi se identifikovali potencijalni efekti zavisni od frekvencije) i različite jačine polja (da se ispitali efekti zavisni od praga jačine polja). Prioritet treba dati istraživanju akutnih efekata, kao što je indukcija fosfena, percepcija, ekscitacija nerava ili mišića i toplotni efekti. Ovo bi bio važan korak ka validaciji referentnih nivoa koje je preporučio ICNIRP kao nezavisna organizacija koja pruža naučne savete i smernice o zdravstvenim i ekološkim uticajima nejonizirajućeg zračenja na zaštitu ljudi i okoline. Bodewein i sar. u [1] takođe preporučuju da sve nove studije treba da imaju za cilj implementaciju visokokvalitetne dozimetrije i minimiziranje izvora opasnosti od pristrasnosti.

U svetlu napretka naučnih istraživanja koja se odnose na povezanost trajanja izloženosti zračenju mobilnih telefona i ekrana sa dugotrajnim rizikom od pojave raka, a koja je ustanovljena epidemiološkim i toksikološkim studijama, sadašnji dokazi su dovoljno jaki da se pređe sa nivoa predostrožnosti na nivo sprečavanja poznatih rizika. Dosadašnja istraživanja sprovedena su na tehnologijama koje su već uvedene, ali postoji izražena potreba da se za sve nove, netestirane tehnologije urade odgovarajuća testiranja pre njihove primene. Epidemiološke studije potvrđuju uticaj ranijih izloženosti zračenju, dok eksperimentalne studije daju indikacije budućeg rizika. Prema tome, eksperimentalne evaluacije i modeliranje su neophodni pre distribucije novih sistema kao što je na primer $5 \mathrm{G}$ mreža za koju nisu dobijeni podaci o bezbednosti. Nepostojanje sistematskog testiranja takvih tehnologija ne treba nipošto mešati sa dokazom sigurnosti ili nepostojanjem rizika. Tvrdi se da će se dodavanjem ove visoke frekvencije $5 \mathrm{G}$ zračenja već složenoj mješavini nižih frekvencija doprinijeti negativnom ishodu javnog zdravlja i iz perspektive fizičkog i mentalnog zdravlja.

Sagledavajući ekspanziju 5G mreže može se reći da se radiofrekventno zračenje sve više prepoznaje kao novi oblik zagađenja životne sredine. Kao i ostale uobičajene izloženosti toksinima, efekti zračenja RF-EMF-a će biti problematični za sagledavanje, ako ne i nemoguće da se 
razjasne efekti izloženosti sa epidemiološkog stanovišta jer više ne ostaje neeksponirana tj. kontrolna grupa [14]. Ovo je posebno važno imajući u vidu da su ovi efekti verovatno uvećani sinergističkom izloženošću toksinima kao i drugim uobičajenim rizičnim ponašanjima. Efekti takođe mogu biti nelinearni tj. u ovom momentu nepredvidivi. Budući da tek treba sagledati i istražiti efekte na prvu generaciju koja je izložena životnom ciklusu „od kolevke do groba“ na ovom nivou radiofrekvencija mikrotalasne (RF EMR) koje je napravio čovek, proći će godine ili decenije pre nego što budu poznate prave zdravstvene posledice.

\section{ZAHVALNOST}

Ovu studiju je podržalo Ministarstvo obrazovanja, nauke i tehnološkog razvoja Republike Srbije, projekti br. 173045 i br. III 44006.

\section{LITERATURA}

[1] L.Bodewein, K. Schmiedchen, D. Dechent, D. Stunder, D. Graefrath, L.Winter, T. Kraus, S. Driessen (2019) Systematic review on the biological effects of electric, magnetic and electromagnetic fields in the intermediate frequency range $(300 \mathrm{~Hz}$ to $1 \mathrm{MHz}$ ) Environmental Research, Volume 171, Pages 247-259

[2] Fernandez PR, Ng KH, Kaur S. Risk Communication Strategies for Possible Health Risks From Radio- Frequency Electromagnetic Fields (RFEMF) Emission by Telecommunication Structures. Health Phys. 2019 Mar 4. doi: 10.1097/ HP.0000000000001037.

[3] https://www.saferemr.com/2017/09/5g-wirelesstechnology-is-5g-harmful-to.html

[4] https://ehtrust.org/key-issues/cell-phone swireless/5g-networks-iot-scientific-overview-human-health-risks/

[5] Wei-Jia Zhi, Li-Feng Wang, Xiang-Jun Hu (2017) Recent advances in the effects of microwave radiation on brains, Military Medical Research 4:29 DOI 10.1186/s40779-017-0139-0

[6] INTERPHONE Study Group. Brain tumour risk in relation to mobile telephone use: results of the INTERPHONE international case-control study. Int J Epidemiol. (2010) Int J Epidemiol. 2010 Jun;39(3):675-94. doi: 10.1093/ije/dyq079. Epub 2010 May 17.
[7] Larjavaara S, Schüz J, Swerdlow A, Feychting M, Johansen C, Lagorio S, Tynes T, Klaeboe L, Tonjer SR, Blettner M, Berg-Beckhoff G, Schlehofer B, Schoemaker M, Britton J, Mäntylä R, Lönn S, Ahlbom A, Flodmark O, Lilja A, Martini S, Rastelli E, Vidiri A, Kähärä V, Raitanen J, Heinävaara S, Auvinen A. Location of gliomas in relation to mobile telephone use: a case-case and case-specular analysis. Am J Epidemiol. 2011 Jul 1;174(1):2-11. doi: 10.1093/aje/ kwr071. Epub 2011 May 24.

[8] Sato Y, Kojimahara N, Yamaguchi N. Simulation of the incidence of malignant brain tumors in birth cohorts that started using mobile phones when they first became popular in Japan. Bioelectromagnetics. 2019 Mar 15. doi: 10.1002/bem.22176.

[9] Coureau G., G. Bouvier, P. Lebailly, P. Fabbro-Peray, A. Gruber, K. Leffondre, J-S. Guillamo, H. Loiseau, S. Mathoulin-Pélissier, R. Salamon, et al. Mobile phone use and brain tumours in the CERENAT case-control study. Occup Environ Med. 2014 Jul; 71(7): 514-522. Published online 2014 May 9. doi: 10.1136/oemed-2013-101754

[10] Morgan LL, Miller AB, Sasco A, Davis DL. Mobile phone radiation causes brain tumors and should be classified as a probable human carcinogen (2A) (review). Int J Oncol. 2015 May;46(5):1865-71. doi: 10.3892/ijo.2015.2908. Epub 2015 Feb 25. Review.

[11] Ramirez-Vazquez R, Gonzalez-Rubio J, Arribas E, Najera A. Characterisation of personal exposure to environmental radiofrequency electromagnetic fields in Albacete (Spain) and assessment of risk perception. Environ Res. 2019 Feb 12;172:109-116. doi: 10.1016/j.envres.2019.02.015.

[12] Meo SA, Almahmoud M, Alsultan Q, Alotaibi N, Alnajashi I, Hajjar WM. Mobile phone base station tower settings adjacent to school buildings: Impact on students' cognitive health. Am J Mens Health. 2018 Dec 7:1557988318816914. doi: $10.1177 / 1557988318816914$.

[13] Miller AB, Morgan LL, Udasin I, Davis DL. Cancer epidemiology update, following the 2011 IARC evaluation of radiofrequency electromagnetic fields (Monograph 102). Environmental Research

[14] Russell CL. 5G wireless telecommunications expansion: Public health and environmental implications. Environmental Research. Available online 11 April 2018. in press. doi:10.1016/j.envres.2018.01.016 